Pre-peer review version. Please refer to the final version published in "Business Strategy and the Environment" Final article doi: 10.1002/bse.1816

\title{
The effects of negative incidents in sustainability reporting on investors' judgments - An experimental study of third-party versus self-disclosure in the realm of sustainable development
}

\author{
Prof. Dr. Daniel Reimsbach \& Prof. Dr. Rüdiger Hahn \\ This is a pre-peer review version of the final article published in "Business Strategy and \\ the Environment". Please refer to the final version published on \\ http://onlinelibrary.wiley.com/journal/10.1002/(ISSN)1099-0836
}

(doi: 10.1002/bse.1816)

\begin{abstract}
This study examines how the disclosure of negative sustainability-related incidents impacts the investment-related judgments of decision makers. Participants in a sequential 2x2 betweensubjects experiment first received a company's financial information, prior to viewing additional sustainability information (by the company and by a non-governmental organization (NGO); with and without negative disclosure). Results indicate that self-reporting of negative incidents does not affect decision makers' stock price estimates and investment decisions compared to judgments based on financial information only. However, third-party disclosure of these incidents by an NGO negatively affects these investment-related judgments. Furthermore, the magnitude of the NGO reporting effect depends on whether the company itself simultaneously reports these incidents. Thus, disclosing negative incidents in sustainability reporting could lose some of its apparent stigma. Instead of avoiding negative reporting altogether, managers might use it as a risk mitigation tool in their reporting strategy. The results also emphasize the power of the often-mentioned NGO-“watchdog” function.
\end{abstract}

\section{Keywords}

Sustainability reporting, voluntary disclosure, negative incidents, investors' judgments, nongovernmental organizations, experiment, reporting strategy

JEL: C91, L31, M14, M41, M48 


\section{Introduction}

In recent years, sustainability reporting has gained increasing attention in business and academia (Fifka, 2011; Hahn and Kühnen, 2013). Especially corporations with a high visibility in terms of industry, size or otherwise seem to proactively disclose sustainability information (e.g., Amran and Haniffa, 2011, Haddock-Fraser and Fraser, 2008; Morhardt, 2010; Vormedal and Ruud, 2009). In this respect, it has been argued that voluntary disclosure of sustainability-related information is often used as an impression management tool (e.g., Hooghiemstra, 2000; Hopwood, 2009; Cho et al., 2010) and that most of the information voluntarily disclosed in sustainability or corporate social responsibility (CSR) reports sheds a positive light on the reporting company (Lougee and Wallace, 2008; Holder-Webb et al., 2009). However, potentially whitewashed sustainability reports raise doubts on the reliability, comparability, and materiality of the published information (Manetti and Becatti, 2009; Dhaliwal et al., 2011). To overcome this drawback, the Global Reporting Initiative (GRI), introduced guidelines for sustainability disclosure (GRI, 2011) challenging companies to provide transparent, complete, and balanced reports. This explicitly includes positive and negative contributions.

While the benefits of a favorable sustainability performance and related reporting for the issuing company have been widely discussed in the literature (e.g., Carroll and Shabana, 2010; Dhaliwal et al., 2011; Kurapatskie and Darnall, 2012), the effects of disclosing negative sustainabilityrelated incidents have largely been neglected in scholarly research (Hahn and Kühnen, 2013; for notable exceptions see, e.g., Chan and Milne, 1999; Coram et al., 2009). Against this background, this study explicitly focuses on investors' reaction to the disclosure of negative incidents. The caveat of such a disclosure is that companies might risk their legitimacy and reputation by disclosing negative incidents (Chan and Milne, 1999; Deegan and Rankin, 1996). Given that sustainability aspects represent value-relevant information to investors (Orlitzky et al., 2003; Dhaliwal et al., 2012) and that investors are a key audience of sustainability reports (Spence, 2009), negative sustainability performance can thus translate into negative financial and stock market performance. However, signaling theory suggests that the negative effects can be mitigated to a certain extent if the addressees perceive the reporting of negative incidents as proactive (Blacconiere and Patten, 1994). Furthermore, additional players such as nongovernmental organizations (NGOs) often adopt a watchdog role uncovering corporate misconduct and (supposedly) negative incidents that could also have devastating effects on 
legitimacy and reputation and thus on shareholder value (see examples in Boele et al., 2001; Grolin, 1998; Lund-Thomsen and Nadvi, 2010; Zadek, 2004). It is thus a worthwhile research aim, to shed light on the impact of companies' sustainability reporting strategies and on respective independent third-party disclosure.

Our research approach is based on an experiment, using a 2 (company includes negative incidents in its sustainability reports or not) $\times 2$ (independent NGO issues its own report on negative incidents or not) between-subjects design. In this experiment, subjects were asked to make a stock price assessment and indicate their willingness to invest in the company in light of financial information only and additional sustainability-related information including negative incidents. Interestingly and opposing the apparently dominant managers' perception that disclosing negative incidents should be avoided (e.g., Lougee and Wallace, 2008; Holder-Webb et al., 2009), our results indicate that disclosure of negative incidents by companies has no significant effect on the stock price estimates nor on the investment decisions compared to judgments based on the disclosure of financial information only. However, disclosure of negative incidents by an independent NGO does have a significant negative effect on these investment-related judgments. Furthermore, we find indications that the magnitude of the NGO's reporting effect depends on whether the company itself simultaneously reports these incidents: The subjects in our experiment seem to punish the companies that were "caught off guard" by negative NGO reports (i.e., companies that do not publish negative incidents themselves but find themselves being accused of certain misconduct relating to sustainability issues).

Overall, our study advances the existing literature by discussing the impact of a truly transparent sustainability disclosure including negative incidents and by analyzing the shareholder value impact of company sustainability reports versus reporting by independent third parties. Our results help to overcome the apparent stigma that negative disclosure has in sustainability reporting strategies. Our findings thus have implications for sustainability and communication managers on how to deal with negative incidents in sustainability disclosure. Furthermore, this study could also influence the behavior of NGOs and their handling of corporate conduct and provide insights for players such as regulators or others (e.g., the GRI) in terms of framing voluntary and mandatory sustainability reporting requirements. 
The remainder of this paper is structured as follows. In the following section, we provide an overview of negative incidents in sustainability reporting before outlining related theories and developing hypotheses. Then, we describe the experimental design and procedure. In the fifth section, we discuss the results and present additional analyses. Finally, we present conclusions and limitations and outline avenues for future research.

\section{Negative Incidents in Sustainability Disclosures}

Most information disclosed in sustainability reports paints a positive picture of the reporting company (Lougee and Wallace, 2008; Holder-Webb et al., 2009). It can be expected, however, that most (if not all) companies of a certain size also have to deal with certain negative aspects of corporate value creation on any of the three sustainability dimensions (economic, ecological, and social; Dyllick and Hockerts, 2002). Because we assume that the economic dimension is covered by traditional financial reporting, we do not focus on this aspect in the paper at hand. From an ecological perspective, negative aspects of corporate activities could stem, for example, from the use of depletable resources or harmful substances. From a social perspective, the alleged occurrence of events such as mistreatment of employees (e.g., discrimination or child labor) or fraud can be regarded as a negative incident.

Several studies on sustainability disclosure refer to different types of mandatory disclosure of negative incidents (e.g., Blacconiere and Patten, 1994; Freedman and Patten, 2004; Lorraine et al., 2004; Shane and Spicer, 1983; Spicer, 1978; and partly Vormedal and Ruud, 2009). When it comes to non-mandatory sustainability reporting, however, only a few scholars specifically investigated disclosure of negative incidents. In the first step toward such issues, Coram et al. (2009) manipulated non-financial performance indicators in a balanced scorecard setting as positive or negative and concluded that these indicators have a significant effect on stock price estimates. Although this conclusion indicates that report users indeed use non-financial information, the indicators in the study were not related to sustainability or CSR but they did include such factors as customer satisfaction ratings and employee training. The study by Chan and Milne (1999) focused more specifically on environmental performance and disclosure. The authors found that investors react strongly and negatively to poor environmental performers, but that there is no significant reaction to the disclosure of good environmental performance. These 
results point to the potential relevance of negative disclosure which is at the center of our study. However, both Chan and Milne (1999) and Coram et al. (2009) analyzed the effects of negative reporting by comparing an overall very positive report with an overall very negative report; the latter, especially, might be deemed unrealistic for voluntary sustainability reporting.

To overcome this limitation, we specifically investigate the impact of a truly transparent sustainability disclosure including negative incidents (see also Hahn and Lülfs, 2013). Furthermore, we also consider the possibility of (simultaneous) reports by independent third parties. Apart from the company itself, other parties also frequently engage in disclosing negative information about specific firms. NGOs, for example, are frequently mentioned for their "watchdog" function, exposing supposedly bad corporate conduct or negative sustainability performance (e.g., Alstine, 2009; Kourula and Laasonen, 2010). The impact can be significant, as NGOs are often regarded as particularly credible and trusted sources of information (e.g., Edelman, 2012). Consequently, Cohen et al. (2011) indicate in their study that NGOs are among the preferred source for investors regarding CSR/sustainability information. Often, critical groups can rely on extensive networks of informants and make sophisticated use of social networks and mass communication tools to increase the pressure on companies to act responsibly, transparently, and accountably (Hahn, 2011).

\section{Theory and Hypotheses}

Among the theories that have been used to explain different aspects of voluntary sustainability disclosure, legitimacy theory (e.g., Rusinko, 2010; Amran and Haniffa, 2011), decision usefulness theory (e.g., Staubus, 2000), and signaling theory (e.g., Campbell et al., 2001) are most important for our analysis. In the following, we propose a brief overview of how these theories interact in the context of negative incident disclosure and derive falsifiable hypotheses. We first refer to legitimacy theory, suggesting that any company needs to have legitimacy in the sense of a social "license to operate," which is granted by society (Rusinko, 2010). Legitimacy, however, is potentially threatened by negative incidents if society perceives that a company is not operating in an acceptable way. In this context, the disclosure of sustainability-related information can be regarded as an instrument to shape the perceived legitimacy of the company 
(Campbell et al., 2003). Sustainability reporting thus represents a link between the legitimacy theory and the decision usefulness theory of accounting as our second theoretical cornerstone.

According to the decision usefulness theory, investors will react in the predicted direction when either positive or negative information is reported, given that this information is considered value relevant (Staubus, 2000; Holm and Rikhardsson, 2008). There is increasing evidence that sustainability aspects indeed represent value-relevant information to investors (Dhaliwal et al., 2012). As such, investors should react to the disclosure of negative incidents in the predicted (i.e., negative) direction (Staubus, 2000). However, the disclosure of negative incidents in sustainability reports differs significantly from financial accounting disclosure, as negative sustainability aspects are much more heterogeneous and not always easily quantifiable (and often not directly pecuniary) compared to negative financial aspects (e.g., reduced earnings). To allow for a differentiated analysis, therefore, we integrate aspects of the signaling theory (e.g., Campbell et al., 2001) in our framework. Signaling theory suggests that negative effects can be mitigated to a certain extent if the addressees perceive the reporting of negative incidents as proactive (Blacconiere and Patten, 1994). The disclosure of negative incidents might then be regarded as a positive signal in terms of actively managing risk, thus helping to avoid future issues. Consequently, instead of solely seeing the negative incident, decision makers might give credit to the company for dealing with the respective aspects (Yang, 2007). Finally, company self-disclosure of negative incidents is often accompanied by the mention of measures taken to overcome these issues; hence, the disclosing company could be regarded as being prepared to deal with the issues at hand. This type of disclosure could signal proactivity and awareness of risk, which is honored by investors, so that the negative disclosure is not classified as a "bad event," or, as Yang (2007, p. 83) posits, "strategic communication means not to hide bad information but to disclose it in a way that is conducive to its solution.” In sum, we do not expect a negative effect on the investment-related judgments of decision makers when a company selfreports negative incidents. In this case, we rather expect that decision makers will rely on the financial information only, and thus, propose the first hypothesis:

H1: Self-reporting of negative incidents by the company will not affect decision makers' investment-related judgments compared to judgments based on the disclosure of financial information only. 
Hypothesizing on the effects of third-party disclosure of negative sustainability-related incidents is rather straight-forward. Extending the legitimacy theory and the decision usefulness theory to reporting by an independent NGO, we expect a negative effect on the investment-related judgments of decision makers. Because no countervailing signaling effects can be expected, we hypothesize:

H2: Third-party reporting of negative incidents by an NGO will negatively affect decision makers' investment-related judgments compared to judgments based on the disclosure of financial information only.

Thus far, we have not considered the possible interaction effects resulting from the reporting behavior of these two actors. According to legitimacy theory, uncovering otherwise withheld information on negative sustainability performance could harm the position of the company in society, thus threatening its operations (Deegan, 2002). It can thus be assumed that the unexpected uncovering of negative sustainability-related information by an independent NGO would lead to an even stronger backlash in public perception. Consistently, signaling theory also acknowledges that not disclosing something can be a signal in itself (Campbell et al., 2001). Therefore, we suggest the following interaction effect:

H3: The magnitude of the effect of an NGO's reporting of negative incidents depends on whether the company itself simultaneously reports negative incidents.

\section{Method and Data}

\section{Experimental design and procedure}

We chose an experimental design for the present study. We aim at investigating how investors use sustainability information (Deegan, 2004) and incorporate this information into their judgment and decision-making process. In this context, experiments involve the use of simulated treatments in an artificial environment, thus allowing the temporal segregation of cause and effect as well as the exclusion of other extraneous factors (Siemsen, 2011). Specifically, we used a sequential $2 \times 2$ factorial between-subjects design with the four groups first receiving financial information (i.e. the earnings press release) and then viewing the company's sustainability report 
with or without negative incidents along with an NGO report or without this report. Figure 1 presents an overview of the experimental conditions.

\section{Insert Figure 1 here}

Figure 2 presents the flow of the experiment which was monitored by both authors. At the beginning, initial instructions were distributed and read to the participants who were randomly assigned to one of the four experimental conditions. After receiving the first part of the materials in an envelope, participants were asked to give an initial stock price assessment for a short-term and a long-term horizon and to make an investment decision (see Appendix B for an overview of the questions). In addition, they could provide comments on their judgments (also see Andersson and Hellman, 2007). Afterwards, the participants received a second envelope containing sustainability information with the specific content depending on the experimental condition as described below. After reading the material, the participants had the chance to revise their initial assessments. Furthermore, they were asked to rate Alphacorp's sustainability performance and to indicate whether they consciously had incorporated sustainability information into their assessments. We thus measured both actual behavior and attitudes (also see Rikhardsson and Holm, 2008). Then the participants were advised to hand back all materials before they received a third and final envelope with the final questionnaire containing manipulation checks and demographic questions.

\section{Insert Figure 2 here}

\section{Study material}

In step 1, all participants received an identical annual earnings press release from a hypothetical firm ("Alphacorp”) in the information technology industry. The press release was modeled on actual reports from a real company listed on the NASDAQ. To prevent any prior knowledge of the company affecting the participants' judgment, we disguised company's identity (Holm and Rikhardsson, 2008). We chose to present a financially healthy company to examine the effects of negative incidents in sustainability reporting in a context free of negative financial connotations (also see Holm and Rikhardsson, 2008).

The press release followed the typical structure. In the first section, financial highlights (e.g. revenue and earnings per share) for the fourth quarter and full year 2011 were provided, followed by a brief management outlook on the financial year 2012. The second section started with a 
narrative providing general information about the company and the industry in which the company operated. Next was a (graphical) comparison of the cumulative five-year total return between Alphacorp, the NASDAQ-100 index, the S\&P 500 index and a peer group index. The third and final section of the earnings press release contained comparative financial statements (balance sheet, income statement, and statement of cash flows) for the financial years 2010-2011 (annual and fourth quarter data). The earnings press release was identical for all experimental conditions.

In step 2, the participants received a shortened sustainability report. Again, this report was modeled on an actual report from a NASDAQ-listed company. The first section was identical for all experimental conditions and provided a summary of the company's code of conduct, as well as information on sustainability highlights, that is, "positive incidents," for 2011. Next was a table giving information on the company's suppliers, and the compliance of their practices and management systems in four areas relating to ethics. We manipulated this information within our experimental conditions (see Appendix A for an overview of sustainability information provided).

The two groups in the upper half of figure 1 received the (tabulated) reporting of negative incidents and corrective actions. The company reported negative incidents in three areas (underage labor, weekly working hours, and discriminatory practices), all occurring at the company's supplier base since such aspects are regarded as typical sustainability-related issues of a company's value chain responsibility (e.g., Phillips and Caldwell, 2005; International Organization for Standardization, 2010) in many industries with worldwide supply chains. Furthermore, issues of such (mal-)practices in worldwide supply chains are increasingly subject to debate in general society so that we assume the mentioned issues to be value-relevant information to investors. Thus, half of the subjects received a report including solely positive information on Alphacorp's sustainability performance while the other half received a balanced report that—in line with the GRI guidelines—encompassed positive and negative information. This allowed us to test for the (incremental) effect of the additional disclosure of negative incidents by the company. The two groups in the left half of figure 1 received an independent industry report issued by a hypothetical NGO called Business Watch. This report listed the negative incidents that were labeled "questionable business conduct" in the experimental condition in which the company did not include negative incidents in their sustainability 
reporting. For the experimental condition where the company reported on negative incidents, this section was labeled "self-reported incidents".

Thus, in sum, we made manipulations only in terms of information provided on negative incidents. Here, however, we had to make slight adjustments in order to make sure that the participants regarded the material as a good proxy of real company data, thus ensuring realistic and serious evaluations. To achieve the necessary degree of realism, the self-reported negative incidents included mentioning of corrective actions which were (again) modeled according to the actual report of the same company which provided the sustainability-related information.

Furthermore and also adding to the realism of our material, these corrective actions were included in the case where the NGO listed the self-reported incidents but excluded from the case where only the NGO reports on the negative incidents. We took this specific detail of our manipulation into account when interpreting the results.

All study materials (i.e. the earnings press release, all sustainability information, and the questionnaires) were pilot tested with a group of doctoral and graduate students who suggested some minor adjustments which were included into the final versions.

\section{Independent and dependent measures}

Our experimental design involves two manipulated (independent) variables. The first independent variable was the inclusion/exclusion of negative incidents in the company's sustainability report. The second independent variable was the presence or absence of an NGO report on negative incidents. There are three dependent variables. The first two variables in our study are the participants' short-term and long-term stock price revisions: In the first questionnaire, which was distributed after the participants had viewed only financial information, participants were given a $\$ 72.00$ stock price on the day preceding the release of the earnings press release. Participants were then asked whether they thought the stock price would increase, decrease or stay the same short-term and long-term. They were also asked to provide a percentage of the short-term and long-term increase or decrease. After receiving the additional sustainability information, participants were asked the same questions again in the second questionnaire, thus giving them the opportunity to revise their initial stock price judgments. We then computed the short-term percentage revision (REVISE1) and long-term percentage revision (REVISE2) in the stock price assessment from the sequence of stock price estimates as our first two dependent variables (also 
see Hopkins, 1996; Brown-Liburd et al., 2012). ${ }^{1}$ We chose a revision measure because we focus on the incremental effect of negative incident reporting on investors' judgments. ${ }^{2}$ The percentage change measure allows standardizing the magnitude of the stock price change regardless of the initial stock price estimate. Furthermore, we decided to include short- and long-term revisions since prior research provided mixed evidence on the decision impact of different time horizons: Chan and Milne (1999), for example, observe that long-term decision horizons increase the impact of sustainability disclosures whereas Rikhardsson and Holm (2008) find more reliance on environmental information for the short-term horizon.Regarding the third independent variable, we follow the approach adopted by Elliott (2006) and asked participants to make an investment decision. In the first questionnaire, participants were advised to assume they already owned a perfectly diversified portfolio and had an additional \$5,000 to invest. Using an 11-point scale ranging from $\$ 0$ to $\$ 5,000$ marked in increments of $\$ 500$, participants were asked to indicate the amount they would be willing to invest in the company. After receiving the additional sustainability information, participants were asked the same question in the second questionnaire. Participants' investment amount revision, in this case computed as an absolute revision, thus represents our third dependent variable (REVISE3). The results for this third dependent variable primarily serve as a robustness check for our analysis of the stock price revision.

\section{Participants}

We used graduate business students (M.Sc. in Business) enrolled in a business strategy course at a large German university (Elliott et al., 2007), thus following prior experimental research on CSR disclosure (Chan and Milne, 1999; Rikhardsson and Holm, 2008). Prior literature stressed that student participants are a good proxy for reasonably informed non-professional investors (Elliott et al., 2007). Over time, such non-professional (or retail) investors have become a significant element in U.S. and European equity markets (Cohen et al., 2011). Furthermore, Libby et al. (2002) caution against the use of professional subjects unless it is necessary to

\footnotetext{
${ }^{1}$ Specifically, we calculated the difference of participants' stock price judgments before and after receiving the sustainability-related information and scaled the outcome by the initial estimates before receiving the sustainability information.

${ }^{2}$ We confirm our main results using an (absolute) dollar change measure as an alternative dependent variable and by performing a split plot (repeated measures) ANOVA. The repeated measure in this instance is the individual investor's long and short-term stock price assessment and the investment amount, before and after receiving additional sustainability information, respectively.
} 
achieve the research goal. We thus think that using student subjects provides a resource-efficient way to give us insights into investors’ sustainability-related judgment and decision making. However, we are aware that graduate students might not generalize to other decision-makers (also see Rikhardsson and Holm, 2008) which we will discuss later on.

The 143 students (62 male) participating in the experiment had taken on average 6.9 (median 6.0) courses related to accounting and/or finance. Sustainability and/or CSR related courses amount to an average of 1.6 (median 1.0) which can be assumed to be a more or less standard value for future managers and non-professional investors when looking at the contemporary status of sustainability education in business schools worldwide (e.g., Wu et al., 2010). 24.5 percent of participants stated that they had purchased common stock or mutual funds over the previous five years. Sixty-six (46.2 percent) participants reported professional work experience (on average 1.2 years). Participants' mean age was 24.7 years. Considering these characteristics, we viewed the participants as a good proxy for (non-professional) investors who are reasonably informed (also see Elliott et al., 2007) and thus allow a stringent test of our hypotheses. ${ }^{3}$

\section{Results and Findings}

\section{Descriptive statistics}

Data collected in the third post-experimental questionnaire allows for a manipulation check. We asked participants three related questions: whether they had received a company sustainability report issued by Alphacorp, whether the sustainability report explicitly mentioned negative incidents, and whether they had also received an industry report on sustainability issued by a NGO. Of the participants, 76.2 percent (109 out of 143) answered all three questions correctly. ${ }^{4}$

\footnotetext{
${ }^{3}$ We checked for randomization imbalances in the demographic variables within our four experimental groups. ANOVA and additional non-parametric tests revealed no statistically significant differences as regards gender, age, coursework, personal investments, and work experience.

${ }^{4}$ Specifically, participants were given three statements on the inclusion of information (e.g. "The material included a so-called 'Industry Report' which was published by an independent NGO”). Participants answered by checking either "true" or "not true". Excluding participants who did not pass the manipulation checks actually (marginally) increases the statistical significance of our results. However, as prior research indicates that sustainability reporting's influence on investors' judgment and decision-making works at least partly on a subconscious level (e.g., Elliott et al., 2012), we decided to report results for the complete subject sample.
} 
Descriptive statistics for participants' stock price assessments and investment decisions before and after viewing sustainability-related information are tabulated in Table 1.

\section{Insert Table 1 here}

Table 2 reports descriptive statistics for our main variables of interest, that is, the short-term and long-term stock price assessment revisions (Panel A) and the investment amount revisions (Panel B) from viewing financial data only to viewing additional sustainability information. The "Company \& NGO negative" condition indicates a change in the short-term (long-term) stock price assessment of -1.22 percent (-0.39 percent), the "Only company negative” condition of 1.59 percent (+1.29 percent), the "Only NGO negative" condition of -3.22 percent (-3.76 percent) and the "No negative" condition of +0.81 percent ( +3.50 percent). Concerning the investment amount revision, the "Company \& NGO negative" condition indicates a change of $+\$ 152.78$, the “Only company negative” condition of $+\$ 29.41$, the "Only NGO negative" condition of $\$ 418.92$, and the "No negative" condition of $+\$ 375.00$. Descriptive statistics thus give the first indication that NGOs' reporting on negative incidents might be an important factor for investors' judgment revisions.

\section{Insert Table 2 here}

\section{Hypothesis Tests}

Table 3 presents the results of the analysis of variance. ${ }^{5}$ We conducted a two-way ANOVA that examined the effect of the company's and the NGO's reporting of negative incidents on investors' judgment revisions. In H1, we hypothesized that the reporting of negative incidents by the company itself would not negatively affect users' stock price estimates. We find that participants' short-term $(\mathrm{F}=0.04 ; \mathrm{p}=0.85)$ and long-term stock price assessment revisions $(\mathrm{F}=$

\footnotetext{
${ }^{5}$ As assessed by the Shapiro-Wilk test, the distributions of our dependent variables for the groups formed by the combination of the company's and the NGO's reporting of negative incidents do not violate normality. However, we also conducted a non-parametric analysis. Specifically, we calculated a two-way ANOVA based on ranked data. We used the Sheirer-Ray-Hare test, an extension of the Kruskal-Walis test. Consistent with the results of the parametric analysis, we find a significant main effect for NGO's reporting of negative incidents $(\mathrm{p}<0.01)$ on participants' long-term stock price revision and their investment amount revision. Also in line with the parametric analysis we find insignificant effects only for the company's reporting on participants' long-term stock price revision. We also find no significant effects on participants' short-term stock price revision. Again consistent with the parametric analysis, we find a significant interaction effect $(\mathrm{p}<0.01)$ only for participants' investment amount revision. Inconsistent with the parametric analysis, we also find a significant main effect for the company's reporting of negative incidents on participants' investment amount revision $(\mathrm{p}<0.01)$.
} 
$0.14 ; p=0.71$ ) are indeed not significantly affected by the reporting of negative incidents by the company itself (see Table 3, Panels A and B). Analysis of the third independent variable shows the robustness of these primary results on the stock price assessment revisions: We find that participants' revision of investment amounts is also unaffected $(F=0.48 ; \mathrm{p}=0.49)$ by the company's reporting of negative incidents (see Table 3, Panel C). The results thus provide strong support for $\mathrm{H} 1$.

\section{Insert Table 3 here}

The second hypothesis posits that the reporting of negative incidents by an NGO will negatively affect users' stock price estimates. We find that participants' long-term ( $F=8.47, \mathrm{p}=0.004$, twotailed) stock price assessment revisions are indeed significantly affected by the NGO's reporting of negative incidents (see Table 3, Panel B). Analysis of the third independent variable again points in the same direction: We find that participants' revision of investment amounts is similarly affected ( $\mathrm{F}=4.20, \mathrm{p}=0.04$, two-tailed) by the NGO's reporting of negative incidents (see Table 3, Panel C). Results for the short-term stock price assessment revisions are directionally consistent, but only marginally significant $(\mathrm{F}=3.05, \mathrm{p}=0.08$, two-tailed). Overall, the results thus support $\mathrm{H} 2$.

In H3, we finally hypothesized that the magnitude of the effect of an NGO's reporting of negative incidents depends on whether the company itself simultaneously reports these incidents. The lines in Figure 3 indicate that NGO's reporting of negative incidents affects investors' stock price revision more if the company itself does not include negative incidents in its sustainability report than when it does. We find that this interaction effect is significant for participants' short-term stock price assessment revision $(\mathrm{F}=4.39 ; \mathrm{p}=0.04)$ while being only marginally significant for participants' long-term stock price assessment revision $(F=3.29$; $p=0.07)$. Furthermore, we observe a significant interaction between the effects of the company's and the NGO's reporting of negative incidents on subjects' investment amount revision $(F=7.86, p=0.01)$. Results thus mostly support H3.

\section{Insert Figure 3 here}

We also examined participants' self-insight by asking them to retrospectively report whether the additional sustainability information had affected their stock price assessments (for a similar approach see, e.g., Weitz and Wright, 1979; Elliott et al., 2012). 39 participants (27.3 percent) 
indicated that the additional sustainability information had not affected their stock price assessments. However, only 24 of the 39 participants (16.8 percent) did not revise their initial assessments. This means that 15 participants (10.9 percent) did revise their stock price assessments from viewing financial data only to viewing additional sustainability information, but they were not aware of this fact. For this (small) subgroup we thus observe an inconsistency between behavior and attitude.

\section{Discussion and Conclusion}

This study examines the effects of disclosing negative incidents in corporate sustainability reports and by an independent third-party on decision-makers investment-related judgments. The participants in a 2 x 2 experimental design were asked to make a stock price assessment and indicate their willingness to invest in the company in light of the financial information only and then to make a revised estimate based on the manipulated factors.

Somewhat counterintuitive to apparently existing manager's perception, but in line with our theory-derived expectations, the results indicate that disclosure of negative incidents by companies has no significant effect either on the stock price estimate (short-term and long-term) or on the investment decision (H1). This finding is important since companies so far predominantly display an avoidance behavior and tend to emphasize positive information in voluntary sustainability reporting (Lougee and Wallace, 2008; Holder-Webb et al., 2009). Moreover, these findings contradict prior experimental research. The few experimental studies that covered negative reporting (Chan and Milne, 1999; Coram et al., 2009) found a negative relationship to shareholder value. The subjects of our experiment, however, do not seem to regard disclosure of negative incidents as harmful per se for company value. A reason might be that in our experiment the participants were offered a balanced corporate report (covering positive and negative aspects) whereas prior experimental research covered negative reporting in a rather extreme way by focusing on purely negative information. Furthermore, the proactive disclosure of negative incidents might have even been regarded as a positive signal in terms of actively managing risk helping to avoid future issues, especially given that the disclosure was accompanied by the mentioning of measures taken to overcome these issues (Hahn and Lülfs, 2013). Hence, the disclosing company in our study could be regarded as being well-prepared to 
deal with the issues at hand. In line with signaling theory (e.g., Campbell et al., 2001), disclosure of this kind thus could signal proactivity and awareness of risks which is honored by investors.

Our other findings were more in line with "traditional" expectations. Participants significantly reacted to sustainability information provided by an NGO. Our behavioral findings thus complement the survey by Cohen et al. (2011) who reveal that third parties (e.g., NGOs) are investors’ preferred source for CSR/sustainability information. Specifically, in our experiment, the disclosure of negative incidents by an independent NGO has a significant negative effect on long-term stock price revisions and investment decisions (H2). In this respect, our results also support prior research indicating that especially long-term decision horizons seem to increase the impact of sustainability disclosures (Rikhardsson and Holm, 2008) as the effects for short-term stock price revisions are less pronounced in our experiment. We also find indications that the magnitude of the effect of an NGO's reporting of negative incidents depends on whether the company itself simultaneously reports these incidents (H3). Our results suggest that investors seem to punish those companies that were "caught off guard" by negative NGO reports (i.e., those companies that do not publish negative incidents themselves but find themselves being accused of certain misconduct relating to sustainability issues. Our findings are thus in line with our proposed theoretical framework. Referring to signaling theory, not disclosing or concealing information might be regarded as a signal in itself (see also Campbell et al., 2001; Bloomfield, 2002). Thus, one possible explanation for the strong negative stock price revisions in the "Only NGO negative" condition is that investors might "preventively" punish the company for other (potential) incidents that have not been uncovered (yet). ${ }^{6}$ On the other hand, our results on the reporting of negative incidents by the company and an NGO suggests that the proactive disclosure preceding the NGO statement mitigates the potential risk of being negatively exposed and signals awareness and a proactive commitment to deal with the issues.

Several implications stem from this outcome. In general, disclosure of negative incidents in sustainability reporting could lose some of the apparent stigma if these incidents are part of an overall balanced sustainability report. Instead of avoiding negative reporting altogether, managers might use it as a kind of risk mitigation tool especially in cases where there is a risk of third

\footnotetext{
${ }^{6}$ When interpreting the strong negative stock price revisions, we again have to consider the manipulations in our experimental materials: In the "Only NGO negative" condition, participants did (and could) not receive information on corrective actions due to the nature of such investigative NGO disclosure.
} 
parties exposing the respective incident or corporate conduct. From an NGO perspective, our results emphasize the power of the often-mentioned "watchdog" function. Uncovering corporate misconduct can indeed hit companies at a sensible point: the share value. Lyon and Maxwell (2011, p. 29) found in their economic model "that activist auditing of corporate disclosure behavior is more likely to induce a firm to become more open and transparent if the firm is likely to have socially or environmentally damaging impacts.” The results of our experiment support this insight. However, NGOs might want to use this power carefully. Sustainability is a highly complex topic (e.g., Hahn, 2011), and it might be that even companies with proactive sustainability management are not aware of individual negative incidents in their value chain. However, publicly uncovering negative incidents in this case could have the effect that the respective firm is deterred from becoming even more accountable. In such cases, a more discreet use of the respective information could be sensible. Finally, other actors in sustainability reporting such as the GRI could use the results of our study as an argument to emphasize the importance of providing a true and fair view of sustainability performance in voluntary disclosure not only from a stakeholder point of view but also from a more company-centered perspective. However, an experimental study is not without limitations. Experiments inevitably involve an over-simplification of the real decision-making process since decision-makers are not gathering their own information (Chan and Milne, 1999). Further research could thus additionally focus on investors' information-seeking behavior specifically regarding negative incidents. In terms of our study material, our manipulation included a subtle specific feature. For reasons discussed above, the negative information provided in the "Company \& NGO negative" and "Only company negative" condition differed slightly from the "Only NGO negative" case since only the former included corrective action proposed by the company who uncovered the respective incidents (see Hahn and Lülfs, 2013, for this strategy). This could have had an impact on the results. We nevertheless purposefully chose this approach to avoid creating an unrealistic scenario which, in the worst case, could have triggered nonsense evaluations and answers by the participants. The results of our approach should thus provide more meaningful insight when looking at typical corporate and NGO reporting behavior, albeit at the cost of a partially blurred view on the triggers of our results. We factored this in by taking the specific nature of our manipulation into account when analyzing and discussing the data. Finally, we used graduate students of business as participants. Although this approach is common (e.g., Elliott et al., 2007; Holm and 
Rikhardsson, 2008), the results may not be generalizable to other groups of decision makers (Rikhardsson and Holm, 2008).

Future studies could try to overcome some of these limitations by complementing our study with different experimental designs (e.g., by using professional analysts as subjects or by investigating investors' reaction to other kinds of negative disclosure). Furthermore, by concentrating on potential investors and share-price issues we discussed the impact of sustainability disclosure from a shareholder value perspective (see, e.g., Moser and Martin, 2012; Deegan, 2004). When shifting to a stakeholder perspective and to a more holistic perspective of information demand, investigating how negative disclosure impacts other stakeholders' perception would be interesting. Finally, different levels of stakeholder orientation in different countries (Williams and Aguilera, 2008) could also affect the value perception in light of negative disclosure; thus, future studies could be conducted in countries with different cultural and social norms.

\section{References}

Alstine J van. 2009. Governance from below: contesting corporate environmentalism in Durban, South Africa. Business Strategy and the Environment 18(2): 108-121.

Amran A, Haniffa R. 2011. Evidence in development of sustainability reporting: a case of a developing country. Business Strategy and the Environment 20(3): 141-156.

Andersson P, Hellman N. 2007. Does Pro Forma Reporting Bias Analyst Forecasts? European Accounting Review 16(2): 277-298.

Blacconiere WG, Patten DM. 1994. Environmental disclosures, regulatory costs, and changes in firm value. Journal of Accounting and Economics 18(3): 357-377.

Bloomfield RJ. 2002. The “Incomplete Revelation Hypothesis” and Financial Reporting. Accounting Horizons 16(3): 233-243.

Boele R, Fabig H, Wheeler D. 2001. Shell, Nigeria and the Ogoni. A study in unsustainable development: I. The story of Shell, Nigeria and the Ogoni people - environment, economy, relationships: conflict and prospects for resolution. Sustainable Development 9(2): 74-86. 
Pre-peer review version. Please refer to the final version published in "Business Strategy and the Environment" Final article doi: 10.1002/bse.1816

Brown-Liburd HL, Cohen JR, Zamora VL. 2012. The Effects of Corporate Social Responsibility Investment, Assurance, and Perceived Fairness on Investors’ Judgments. SSRN Electronic Journal. DOI: 10.2139/ssrn.1985839.

Campbell D, Craven B, Shrives P. 2003. Voluntary social reporting in three FTSE sectors: a comment on perception and legitimacy. Accounting, Auditing \& Accountability Journal 16(4): 558-581.

Campbell D, Shrives P, Bohmbach-Saager H. 2001. Voluntary Disclosure of Mission Statements in Corporate Annual Reports: Signaling What and To Whom? Business and Society Review 106(1): 65-87.

Carroll AB, Shabana KM. 2010. The Business Case for Corporate Social Responsibility: A Review of Concepts, Research and Practice. International Journal of Management Reviews 12(1): 85-105.

Chan CCC, Milne MJ. 1999. Investor reactions to corporate environmental saints and sinners: an experimental analysis. Accounting and Business Research 29(4): 265-279.

Cho CH, Roberts RW, Patten DM. 2010. The language of US corporate environmental disclosure. Accounting, Organizations and Society 35(4): 431-443.

Cohen J, Holder-Webb L, Nath L, Wood D. 2011. Retail Investors' Perceptions of the DecisionUsefulness of Economic Performance, Governance, and Corporate Social Responsibility Disclosures. Behavioral Research in Accounting 23(1): 109-129.

Coram PJ, Monroe GS, Woodliff DR. 2009. The Value of Assurance on Voluntary Nonfinancial Disclosure: An Experimental Evaluation. Auditing: A Journal of Practice \& Theory 28(1): $137-151$.

Deegan C. 2002. Introduction: The legitimising effect of social and environmental disclosures - a theoretical foundation. Accounting, Auditing \& Accountability Journal 15(3): 282-311.

Deegan C. 2004. Environmental disclosures and share prices—a discussion about efforts to study this relationship. Accounting Forum 28(1): 87-97.

Deegan C, Rankin M. 1996. Do Australian companies report environmental news objectively? An analysis of environmental disclosures by firms prosecuted successfully by the 
Pre-peer review version. Please refer to the final version published in "Business Strategy and the Environment" Final article doi: 10.1002/bse.1816

Environmental Protection Authority. Accounting, Auditing \& Accountability Journal 9(2): 50-67.

Dhaliwal DS, Li OZ, Tsang A, Yang YG. 2011. Voluntary Nonfinancial Disclosure and the Cost of Equity Capital: The Initiation of Corporate Social Responsibility Reporting. The Accounting Review 86(1): 59-100.

Dhaliwal DS, Radhakrishnan S, Tsang A, Yang YG. 2012. Nonfinancial Disclosure and Analyst Forecast Accuracy: International Evidence on Corporate Social Responsibility Disclosure. The Accounting Review 87(3): 723-759.

Dyllick T, Hockerts K. 2002. Beyond the business case for corporate sustainability. Business Strategy and the Environment 11(2): 130-141.

Edelman. 2012. 2012 Edelman Trust Barometer Executive Summary. Edelman: n.p.

Elliott WB. 2006. Are Investors Influenced by Pro Forma Emphasis and Reconciliations in Earnings Announcements? The Accounting Review 81(1): 113-133.

Elliott WB, Hodge FD, Kennedy JJ, Pronk M. 2007. Are M.B.A. Students a Good Proxy for Nonprofessional Investors? The Accounting Review 82(1): 139-168.

Elliott WB, Jackson KE, Peecher ME, White BJ. 2012. Mitigating the Unintended Effect of Corporate Social Responsibility Performance on Investors' Estimates of Fundamental Value. SSRN Electronic Journal. DOI: 10.2139/ssrn.1864827.

Fifka MS. 2011. Corporate Responsibility Reporting and its Determinants in Comparative Perspective - a Review of the Empirical Literature and a Meta-analysis. Business Strategy and the Environment: Early View. DOI: 10.1002/bse.729.

Freedman M, Patten DM. 2004. Evidence on the pernicious effect of financial report environmental disclosure. Accounting Forum 28(1): 27-41.

GRI. 2011. Sustainability Reporting Guidelines. GRI: Amsterdam.

Grolin J. 1998. Corporate legitimacy in risk society: the case of Brent Spar. Business Strategy and the Environment 7(4): 213-222. 
Pre-peer review version. Please refer to the final version published in "Business Strategy and the Environment" Final article doi: 10.1002/bse.1816

Haddock-Fraser J, Fraser I. 2008. Assessing corporate environmental reporting motivations: differences between 'close-to-market' and 'business-to-business' companies. Corporate Social Responsibility and Environmental Management 15(3): 140-155.

Hahn R. 2011. Integrating corporate responsibility and sustainable development: A normativeconceptual approach to holistic management thinking. Journal of Global Responsibility 2(1): $8-22$.

Hahn R., Kühnen M. 2013. Determinants of sustainability reporting: A review of results, trends, theory, and opportunities in an expanding field of research. Journal of Cleaner Production, in press. doi: 10.1016/j.jclepro.2013.07.005

Hahn R, Lülfs R, 2013. Legitimizing negative aspects in GRI-oriented sustainability reporting: A qualitative analysis of corporate disclosure strategies. Journal of Business Ethics, in press. doi: 10.1007/s10551-013-1801-4

Holder-Webb L, Cohen JR, Nath L, Wood D. 2009. The Supply of Corporate Social Responsibility Disclosures Among U.S. Firms. Journal of Business Ethics 84(4): 497-527.

Holm C, Rikhardsson P. 2008. Experienced and Novice Investors: Does Environmental Information Influence Investment Allocation Decisions? European Accounting Review 17(3): 537-557.

Hooghiemstra R. 2000. Corporate Communication and Impression Management - New Perspectives Why Companies Engage in Corporate Social Reporting. Journal of Business Ethics 27(1/2): 55-68.

Hopkins PE. 1996. The Effect of Financial Statement Classification of Hybrid Financial Instruments on Financial Analysts' Stock Price Judgments. Journal of Accounting Research 34: $33-50$.

Hopwood AG. 2009. Accounting and the environment. Accounting, Organizations and Society 34(3-4): 433-439.

International Organization for Standardization. 2010. ISO 26000 - Guidance on Social Responsibility. International Organization for Standardization: Geneva. 
Pre-peer review version. Please refer to the final version published in "Business Strategy and the Environment" Final article doi: 10.1002/bse.1816

Kourula A, Laasonen S. 2010. Nongovernmental Organizations in Business and Society, Management, and International Business Research: Review and Implications From 1998 to 2007. Business \& Society 49(1): 35-67.

Kurapatskie B, Darnall N. 2012. Which Corporate Sustainability Activities are Associated with Greater Financial Payoffs? Business Strategy and the Environment: Early View. DOI: 10.1002/bse.1735.

Libby R, Bloomfield R, Nelson MW. 2002. Experimental research in financial accounting. Accounting, Organizations and Society 27(8): 775-810.

Lorraine N, Collison D, Power D. 2004. An analysis of the stock market impact of environmental performance information. Accounting Forum 28(1): 7-26.

Lougee B, Wallace J. 2008. The Corporate Social Responsibility (CSR) Trend. Journal of Applied Corporate Finance 20(1): 96-108.

Lund-Thomsen P, Nadvi K. 2010. Global value chains, local collective action and corporate social responsibility: a review of empirical evidence. Business Strategy and the Environment 19(1): 1-13.

Lyon TP, Maxwell JW. 2011. Greenwash: Corporate Environmental Disclosure under Threat of Audit. Journal of Economics \& Management Strategy 20(1): 3-41.

Manetti G, Becatti L. 2009. Assurance Services for Sustainability Reports: Standards and Empirical Evidence. Journal of Business Ethics 87(S1): 289-298.

Morhardt JE. 2010. Corporate social responsibility and sustainability reporting on the Internet. Business Strategy and the Environment 19: 436-452. DOI: 10.1002/bse.657.

Moser DV, Martin PR. 2012. A Broader Perspective on Corporate Social Responsibility Research in Accounting. The Accounting Review 87(3): 797-806.

Orlitzky M, Schmidt FL, Rynes SL. 2003. Corporate Social and Financial Performance: A MetaAnalysis. Organization Studies 24(3): 403-441.

Phillips R, Caldwell CB. 2005. Value Chain Responsibility: A Farewell to Arm's Length. Business and Society Review 110(4): 345-370. 
Pre-peer review version. Please refer to the final version published in "Business Strategy and the Environment" Final article doi: 10.1002/bse.1816

Rikhardsson P, Holm C. 2008. The effect of environmental information on investment allocation decisions - an experimental study. Business Strategy and the Environment 17(6): 382-397. DOI: 10.1002/bse.536.

Rusinko CA. 2010. Integrating Sustainability in Management and Business Education: A Matrix Approach. Academy of Management Learning \& Education 9(3): 507-519.

Shane PB, Spicer BH. 1983. Market Response to Environmental Information Produced Outside the Firm. The Accounting Review 58(3): 521-538.

Siemsen E. 2011. The usefulness of behavioral laboratory experiments in supply chain management research. Journal of Supply Chain Management 47(3): 17-18.

Spence C. 2009. Social and environmental reporting and the corporate ego. Business Strategy and the Environment 18(4): 254-265.

Spicer BH. 1978. Investors, Corporate Social Performance and Information Disclosure: An Empirical Study. The Accounting Review 53(1): 94-111.

Staubus GJ. 2000. The decision-usefulness theory of accounting: A limited history. Garland Pub.: New York.

Vormedal I, Ruud A. 2009. Sustainability reporting in Norway - an assessment of performance in the context of legal demands and socio-political drivers. Business Strategy and the Environment 18(4): 207-222.

Weitz B, Wright P. 1979. Retrospective Self-Insight on Factors Considered in Product Evaluation. Journal of Consumer Research 6(3): 280.

Williams CA, Aguilera RV. 2008. Corporate social responsibility in comparative perspective. In The Oxford handbook of corporate social responsibility, Crane A, McWilliams A, Matten D, Moon J, Siegel DS (eds.). Oxford University Press: Oxford ; New York; 452-472.

Wu YJ, Huang S, Kuo L, Wen-Hsiung W. 2010. Management Education for Sustainability: A Web-Based Content Analysis. Academy of Management Learning \& Education 9(3): 520531. 
Pre-peer review version. Please refer to the final version published in "Business Strategy and the Environment" Final article doi: 10.1002/bse.1816

Yang K. 2007. Examining Perceived Honest Performance Reporting by Public Organizations:

Bureaucratic Politics and Organizational Practice. Journal of Public Administration Research and Theory 19(1): 81-105.

Zadek S. 2004. The path to corporate responsibility. Harvard Business Review 82(12): 125-132.

Figures and Tables

Figure 1: Experimental groups

Third party (NGO) reports negative incidents

\begin{tabular}{|c|c|c|c|}
\hline \multirow{3}{*}{ 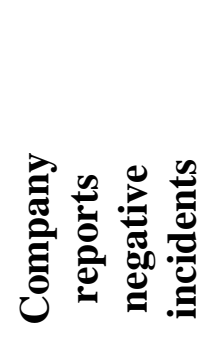 } & & yes & no \\
\hline & $\stackrel{\mathscr{D}}{\mathrm{D}}$ & $\begin{array}{c}\text { Company \& NGO } \\
\text { neqative }\end{array}$ & Only company negative \\
\hline & g & Only NGO negative & No negative \\
\hline
\end{tabular}

Figure 2: Flow of the experiment 
Pre-peer review version. Please refer to the final version published in "Business Strategy and the Environment" Final article doi: 10.1002/bse.1816

Step 1: Participants receive Alphacorp‘s 2011 earnings press release together with Questionnaire \#1 and give initial stock price assessment (and make other investment-related judgments)

Step 2: $\begin{array}{r}\text { Participants receive sustainability information (see Figure 1) together with } \\ \text { Questionnaire \#2 and can revise their initial stock price assessment (and the } \\ \text { other investment related judgments) }\end{array}$
Step 3: $\quad \begin{gathered}\text { Participants receive Questionnaire \#3 and rate Alphacorp’s sustainability } \\ \text { performance and they respond to manipulation and demographic questions }\end{gathered}$

Figure 3: Interaction Effect 
Pre-peer review version. Please refer to the final version published in "Business Strategy and the Environment" Final article doi: 10.1002/bse.1816

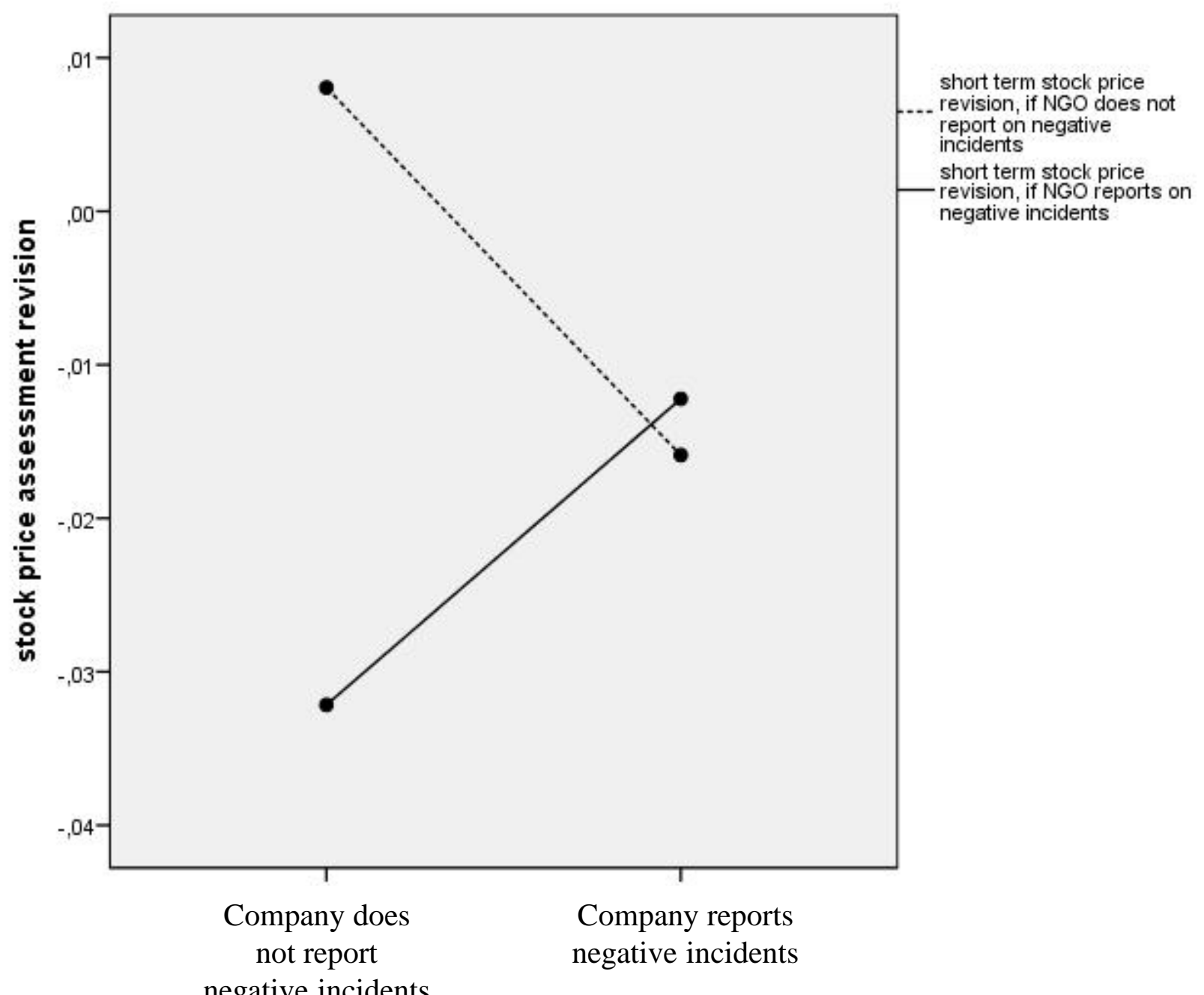


Pre-peer review version. Please refer to the final version published in "Business Strategy and the Environment"

Final article doi: 10.1002/bse.1816

\section{Table 1: Investor Assessments}

Panel A: Stock price assessments after viewing financial data only (short-term/long-term) Descriptive statistics (mean [SD])

\begin{tabular}{|c|c|c|c|c|c|c|c|c|c|c|}
\hline \multirow{8}{*}{ 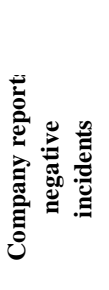 } & \multirow{4}{*}{ YES } & \multicolumn{6}{|c|}{ Third party (e.g. NGO) reports negative incidents } & \multirow[b]{2}{*}{$\mathbf{n}$} & \multirow{2}{*}{\multicolumn{2}{|c|}{ By Row }} \\
\hline & & n & \multicolumn{2}{|c|}{ YES } & $\mathbf{n}$ & \multicolumn{2}{|c|}{ NO } & & & \\
\hline & & 36 & 75.58 & 79.30 & 34 & 76.83 & 76.83 & 70 & 76.19 & 78.10 \\
\hline & & & [5.73] & {$[9.26]$} & & [6.11] & [12.73] & & [5.91] & [11.07] \\
\hline & NO & 37 & 75.97 & 77.64 & 36 & 75.18 & 74.44 & 73 & 75.58 & 76.06 \\
\hline & & & [5.04] & [9.48] & & [5.04] & [10.50] & & [5.02] & [9.90] \\
\hline & By column & 73 & 75.78 & 78.46 & 70 & 75.98 & 75.60 & 143 & 75.88 & 77.06 \\
\hline & & & [5.36] & [9.34] & & [5.60] & [11.46] & & [5.46] & [10.50] \\
\hline
\end{tabular}

Panel A report by-cell mean (\$), [standard deviation] and number of participants which provided stock price assessments. Stock price assessment is computed from the percent change in stock price assessment from the initial $\$ 72$ benchmark provided after viewing financial data only.

Panel B Stock price assessments after viewing additional sustainability information (short-term/long-term) Descriptive statistics (mean [SD])

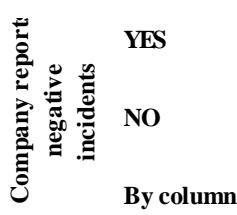

Third party (e.g. NGO) reports negative incidents

\begin{tabular}{|c|c|c|c|c|c|c|c|c|}
\hline n & \multicolumn{2}{|c|}{ YES } & n & \multicolumn{2}{|c|}{ NO } & $\mathbf{n}$ & \multicolumn{2}{|c|}{ By Row } \\
\hline \multirow[t]{2}{*}{36} & 74.38 & 78.74 & 34 & 75.58 & 77.21 & 70 & 74.96 & 77.99 \\
\hline & [3.56] & [8.38] & & [5.94] & [11.47] & & [4.86] & [9.96] \\
\hline \multirow[t]{2}{*}{37} & 73.32 & 74.74 & 36 & 75.62 & 76.58 & 73 & 74.46 & 75.65 \\
\hline & [5.98] & [12.12] & & [4.24] & [9.83] & & [5.29] & [11.02] \\
\hline \multirow[t]{2}{*}{73} & 73.84 & 76.71 & 70 & 75.60 & 76.89 & 143 & 74.70 & 76.80 \\
\hline & [4.93] & [10.57] & & [5.10] & [10.58] & & [5.07] & [10.54] \\
\hline
\end{tabular}

Panel B report by-cell mean (\$), [standard deviation] and number of participants which provided stock price assessments. Stock price assessment is computed from the percent change in stock price assessment from the initial $\$ 72$ benchmark provided after viewing additional sustainability information.

Panel C: Investment decision after viewing financial data only

Descriptive statistics (mean [SD])

\begin{tabular}{|c|c|c|c|c|c|c|c|}
\hline \multirow{6}{*}{ } & & \multicolumn{4}{|c|}{ Third party (e.g. NGO) reports negative incidents } & \multirow[b]{2}{*}{$\mathbf{n}$} & \multirow[b]{2}{*}{ By Row } \\
\hline & & n & YES & $\mathbf{n}$ & NO & & \\
\hline & YES & 36 & $2,194.44$ & 34 & $1,676.47$ & $\overline{70}$ & $1,942.86$ \\
\hline & & & {$[1,425.67]$} & & {$[1,205.31]$} & & {$[1,339.32]$} \\
\hline & NO & 37 & $1,864.86$ & 36 & $1,722.22$ & 73 & $1,794.52$ \\
\hline & & & {$[1,289.10]$} & & {$[1,136.69]$} & & {$[1,210.02]$} \\
\hline & By column & 73 & $2,027.40$ & 70 & $1,770.00$ & 143 & $1,867.13$ \\
\hline & & & {$[1,358.85]$} & & {$[1,162.21]$} & & {$[1,272.61]$} \\
\hline
\end{tabular}

Panel C report by-cell mean (\$), [standard deviation] and number of participants which provided investment amounts. Participants provided investment amounts using a scale marked in increments of $\$ 500$ with the endpoints of $\$ 0$ and $\$ 5,000$ after viewing financial information only

Panel D: Investment decision after viewing additional sustainability information

Descriptive statistics (mean [SD])

\begin{tabular}{|c|c|c|c|c|c|c|c|}
\hline \multirow{7}{*}{ 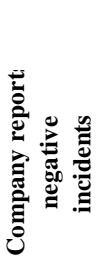 } & & \multicolumn{4}{|c|}{ Third party (e.g. NGO) reports negative incidents } & \multirow[b]{2}{*}{$\mathbf{n}$} & \multirow[b]{2}{*}{ By Row } \\
\hline & & $\mathbf{n}$ & YES & $\mathbf{n}$ & NO & & \\
\hline & YES & 36 & $2,347.22$ & 34 & $1,705.88$ & 70 & $2,035.71$ \\
\hline & & & {$[1,458.08]$} & & {$[1,206.78]$} & & {$[1,370.82]$} \\
\hline & NO & 37 & $1,445.95$ & 36 & 2,097.22 & 73 & $1,767.12$ \\
\hline & & & {$[1,418.06]$} & & {$[1,263.89]$} & & {$[1,374.58]$} \\
\hline & By column & 73 & $1,890.41$ & 70 & $1,907.14$ & 143 & $1,898.60$ \\
\hline & & & {$[1,498.26]$} & & {$[1,243.22]$} & & {$[1,374.52]$} \\
\hline
\end{tabular}

Panel C report by-cell mean (\$), [standard deviation] and number of participants which provided investment amounts. Participants provided investment amounts using a scale marked in increments of $\$ 500$ with the endpoints of $\$ 0$ and $\$ 5,000$ after viewing additional sustainability information. 
Pre-peer review version. Please refer to the final version published in "Business Strategy and the Environment" Final article doi: 10.1002/bse.1816

\section{Table 2: Investor Assessment Revisions}

\section{Panel A: Stock price assessment revisions (short-term/long-term) \\ Descriptive statistics (mean [SD])}

Third party (e.g. NGO) reports negative incidents

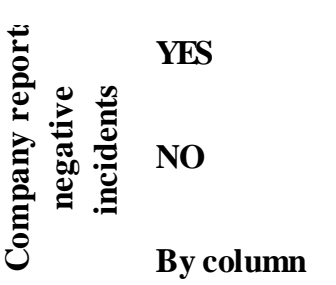

\begin{tabular}{|c|c|c|c|c|c|c|c|c|}
\hline $\mathbf{n}$ & \multicolumn{2}{|c|}{ YES } & \multirow{2}{*}{$\frac{\mathbf{n}}{34}$} & \multicolumn{2}{|c|}{ NO } & \multirow{2}{*}{$\frac{\mathbf{n}}{70}$} & \multicolumn{2}{|c|}{ By Row } \\
\hline \multirow[t]{2}{*}{36} & -0.012 & -0.004 & & $-0.016 * * *$ & 0.013 & & $-0.014^{* *}$ & 0.004 \\
\hline & [0.064] & [0.060] & & [0.030] & [0.091] & & [0.050] & {$[0.076]$} \\
\hline \multirow[t]{2}{*}{37} & $-0.032 * *$ & $-0.038 * *$ & 36 & 0.008 & $0.035^{*}$ & 73 & -0.012 & -0.002 \\
\hline & [0.086] & [0.104] & & [0.055] & [0.104] & & [0.075] & [0.110] \\
\hline \multirow[t]{2}{*}{73} & $-0.022 * *$ & $-0.021 * *$ & 70 & -0.004 & $0.024 * *$ & 143 & $-0.013 * *$ & 0.001 \\
\hline & [0.076] & [0.087] & & [0.046] & [0.098] & & [0.064] & {$[0.09$} \\
\hline
\end{tabular}

Panel A reports by cell mean, [standard deviation] and number of participants which provided stock price assessments. Stock price revision is computed from the difference in the absolute stock price assessment before and after viewing additional sustainability information and scaling the outcome by the initial estimates before receiving the sustainability information. *, ** and $* * *$ represent the results from a two-tailed t-test that the cell mean is significantly different from zero at the $0.1,0.05$ and 0.01 level.

\section{Panel B: Investment decision revisions}

Descriptive statistics (mean [SD])

\begin{tabular}{|c|c|c|c|c|c|c|c|}
\hline \multirow{8}{*}{ 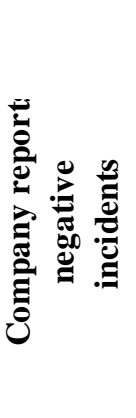 } & & \multicolumn{4}{|c|}{ Third party (e.g. NGO) reports negative incidents } & \multirow[b]{2}{*}{$\mathbf{n}$} & \multirow[b]{2}{*}{ By Row } \\
\hline & & $\mathbf{n}$ & YES & $\mathbf{n}$ & NO & & \\
\hline & YES & 36 & 152.78 & 34 & 29.41 & 70 & 92.86 \\
\hline & & & {$[570.96]$} & & [695.67] & & [632.99] \\
\hline & NO & 37 & $-418.92 *$ & 36 & $375.00 * *$ & 73 & -27.40 \\
\hline & & & {$[1,497.75]$} & & {$[839.86]$} & & {$[1,274.45]$} \\
\hline & By column & 73 & -136.99 & 70 & $207.14 * *$ & 143 & 31.47 \\
\hline & & & {$[1,167.44]$} & & [787.09] & & {$[1,010.89]$} \\
\hline
\end{tabular}

Panel B report by cell mean, [standard deviation] and number of participants which provided investment amounts. Investment decision revision is computed from the absolute change in the investment amount from just viewing financial data to the investment amount after viewing additional sustainability information. $*$, ** and *** represent the results from a two-tailed t-test that the cell mean is significantly different from zero at the 0.1, 0.05 and 0.01 level. 
Pre-peer review version. Please refer to the final version published in "Business Strategy and the Environment" Final article doi: 10.1002/bse.1816

Table 3: Investor Assessment Revisions

\begin{tabular}{lcccccc}
\hline Panel A: Results of ANOVA $^{\text {a }}$ & (short-term stock price assessment revision) & & \\
\hline Source & Prediction & DF & SS & MS & F-statistic & p-value \\
\hline Corrected Model & & 3 & 0.030 & 0.010 & 2.542 & 0.059 \\
& & & & & & \\
Company reports & H1+ & 1 & 0.000 & 0.000 & 0.036 & 0.849 \\
NGO reports & H2+ & 1 & 0.012 & 0.012 & 3.049 & 0.083 \\
Company reports x NGO reports & $\mathbf{H 3 +}$ & 1 & 0.017 & 0.017 & 4.392 & 0.038 \\
& & & & & & \\
Error & & 139 & 0.544 & 0.004 & & \\
\hline
\end{tabular}

a Panel A report reports the results of ANOVA of the short-term stock price assessment revision on variables defined in Table 1.

Panel B: Results of ANOVA ${ }^{b}$ (long-term stock price assessment revision)

\begin{tabular}{lcccccc}
\hline Source & Prediction & DF & SS & MS & F-statistic & p-value \\
\hline Corrected Model & & 3 & 0.102 & 0.034 & 4.052 & 0.009 \\
& & & & & & \\
Company reports & $\mathbf{H 1}+$ & 1 & 0.001 & 0.001 & 0.143 & 0.706 \\
NGO reports & $\mathbf{H 2 +}$ & 1 & 0.071 & 0.071 & 8.474 & 0.004 \\
Company reports x NGO reports & $\mathbf{H 3 +}$ & 1 & 0.028 & 0.028 & 3.294 & 0.072 \\
& & & & & \\
Error & & & & \\
\hline b Panel B report reports the results of ANOVA of the long-term stock price assessment revision on variables defined in Table 1.
\end{tabular}

b Panel B report reports the results of ANOVA of the long-term stock price assessment revision on variables defined in Table 1.

\begin{tabular}{|c|c|c|c|c|c|c|}
\hline \multicolumn{7}{|c|}{ Panel C: Results of ANOVAc (investment amount revision) } \\
\hline Source & Prediction & DF & SS & MS & F-statis tic & p-value \\
\hline Corrected Model & & 3 & $12,283,824.39$ & $4,094,608.13$ & 4.285 & 0.006 \\
\hline Company reports & H1+ & 1 & $456,496.58$ & $456,496.58$ & 0.478 & 0.491 \\
\hline NGO reports & $\mathbf{H} 2+$ & 1 & $4,014,856.20$ & $4,014,856.20$ & 4.202 & 0.042 \\
\hline Company reports x NGO reports & H3+ & 1 & $7,512,983.17$ & $7,512,983.17$ & 7.862 & 0.006 \\
\hline Error & & 139 & $132,824,567.21$ & $955,572.43$ & & \\
\hline
\end{tabular}




\section{Appendix A \\ Overview of Provided Sustainability Information}

\begin{tabular}{|c|c|}
\hline Description of report content & $\begin{array}{l}\text { Group that } \\
\text { received report }\end{array}$ \\
\hline $\begin{array}{l}\text { Alphacorp Sustainability Report (without negative incidents) } \\
\text { - } \quad \text { Code of conduct (extract) } \\
\text { - } \\
\text { Sustainability highlights from the previous year (i.e., a number of } \\
\text { positive highlights regarding the ecological and social } \\
\text { performance in the supply chain) } \\
\text { - } \\
\text { Audit data (i.e., selected data from supplier audits on ethical } \\
\text { issues) }\end{array}$ & $\begin{array}{l}\text { “Only NGO } \\
\text { negative” } \\
\text { “No negative” }\end{array}$ \\
\hline $\begin{array}{l}\text { Alphacorp Sustainability Report (including negative incidents) } \\
\text { - } \quad \text { Same as above plus } \\
\text { - } \quad \text { Disclosure of a number of negative incidents in the supply chain } \\
\text { (e.g., "6 active and } 13 \text { historical cases of underage labor at } 5 \\
\text { supplier facilities" } \\
\text { - Corrective action for each incident (e.g., "We required the } \\
\text { suppliers to support the young workers' return to school and to } \\
\text { improve their management systems to prevent recurrences" }\end{array}$ & $\begin{array}{l}\text { "Company \& } \\
\text { NGO } \\
\text { negative” } \\
\text { "Only company } \\
\text { negative" }\end{array}$ \\
\hline $\begin{array}{l}\text { Independent NGO report (including "self-reported incidents”) } \\
\text { - } \quad \text { Brief section on the NGOs mission (“... committed to improve the } \\
\text { transparency of business activities ...”) } \\
\text { - } \\
\text { Section repeating the incidents and corrective action from } \\
\text { Alphacorp Sustainability Report (including negative incidents) } \\
\text { - } \text { Brief pledge to further monitor the company closely and its } \\
\text { adherence to the promised corrective action }\end{array}$ & $\begin{array}{c}\text { “Company \& } \\
\text { NGO } \\
\text { negative” }\end{array}$ \\
\hline $\begin{array}{l}\text { Independent NGO report (including “uncovered incidents”) } \\
-\quad \text { Brief section on the NGOs mission (see above) } \\
\text { - } \quad \text { Section highlighting the same negative incidents as above } \\
\text { - } \quad \text { Brief explanation of how the incidents were uncovered ("media } \\
\\
\text { reports as well as our own investigations") }\end{array}$ & $\begin{array}{l}\text { “Only NGO } \\
\text { negative" }\end{array}$ \\
\hline
\end{tabular}


Pre-peer review version. Please refer to the final version published in "Business Strategy and the Environment" Final article doi: 10.1002/bse.1816

\section{Appendix B \\ Selected Questions from Questionnaires 1, 2, and 3}

\section{Questionnaires \#1 and\# 2:}

Please answer the following questions by checking the boxes and/or by giving a specific value

(Questionnaire 2: You have now the chance to revise your initial assessments):

1) Alphacorp's price per share for common stock was $\$ 72$ on the day preceding the release of the earnings press release.

a) Which short-term scenario do you expect? (please choose only one (!) scenario):

The stock price will decrease in the short-term, i.e. by___ $\%$

$\square$ The stock price will increase in the short-term, i.e. by___ $\%$

The stock price will not change in the short-term.

b) Which long-term scenario do you expect? (please choose only one (!) scenario):

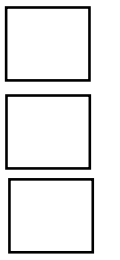

The stock price will decrease in the long-term, i.e. by__ \%

The stock price will increase in the long-term, i.e. by___ $\%$

The stock price will not change in the short-term.

2) Assume that you already own a diversified stock portfolio and you have another $\$ 5,000$ to invest. Please indicate on the scale below how much (if any) of the $\$ 5,000$ you would invest in Alphacorp's common stock.

Assume that the distances between the boxes are equal!

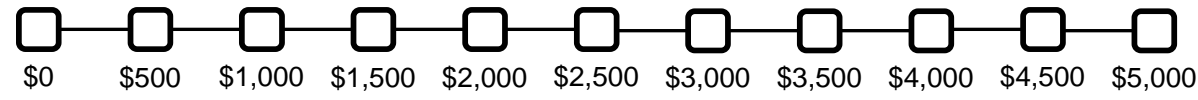

\section{Questionnaire \#2:}

3) Please indicate on the scale below your perception of Alphacorp's sustainability performance! Assume that the distances between the boxes are equal!

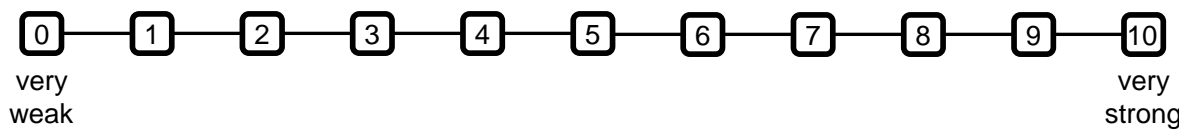

\section{Questionnaire \#3:}

4) I considered information on "Sustainability" as relevant when assessing of the development of Alphacorp's stock price.

O true $\quad$ O not true 